\title{
Luís Saia e a evolução arquitetônica regional: da morada paulista às práticas de proteção ao patrimônio cultural nacional ${ }^{1}$
}

\section{Resumo}

Neste artigo trato das ações federais de proteção ao patrimônio cultural em São Paulo, com destaque à figura de Luis Saia, tomando como eixo central da reflexão a produção historiográfica que forneceu sentido e efetividade a esse conjunto de práticas. Pretendo demonstrar como a produção de uma narrativa relacionada à noção de "evolução cultural paulista" permitiu orientar um conjunto de práticas preservacionistas, num longo período que se inicia com uma frustração inicial dos projetos intelectuais paulistas sob a liderança de Mário de Andrade e deságuam num momento em que a expansão urbana cobrava novos significados ao patrimônio cultural nacional.

Palavras-chave: Luís Saia, história da arquitetura, patrimônio cultural.

\section{ntrodução}

1 Este artigo foi produzido a partir dos resultados das pesquisas realizadas, primeiramente, entre 2008 e 2010, para o Programa de Pós-Graduação em História da Universidade Federal de Ouro Preto (LOWANDE, 2010), em seguida, em pesquisa realizada para o Centro de Pesquisa e Documentação do Instituto do Patrimônio Histórico e Artístico Nacional (COPEDOC/IPHAN), entre 2011 e 2012, com o apoio da Fundação Darcy Ribeiro e, por fim, para o doutorado em História, ainda em andamento, realizado no Instituto de Filosofia e Ciências Humanas da Universidade Estadual de Campinas (IFCH/UNICAMP), no qual pude contar, por mais de um ano, com bolsa oferecida CNPq.

2 Seria impossível reconstituir aqui a literatura que tem tratado desses problemas desde que a historiografia ...continua próxima página...

\section{Walter Francisco Figueiredo Lowande}

Historiador, doutorando do Programa de Pós-Graduação em História do Instituto de Filosofia e Ciências Humanas da Universidade Estadual de Campinas (IFCH/UNICAMP), professor do Departamento de Ciências Humanas da Universidade Federal de Alfenas, MG (UNIFAL-MG), Rua Gabriel Monteiro da Silva, 700, Centro, CEP 37130-000, Alfenas, MG, (35) 3299-1418, walterlowande@gmail.com
Qual é a relevância de uma trajetória individual para as interpretações de cunho historiográfico?

Para uma historiografia tradicional, que se ampara sobretudo no lugar comum segundo o qual a história é uma mestra para a vida presente (historia magistra vitae), a biografia adquire a função de exemplo de vida a ser repetido. A seleção e apresentação do sujeito biografado se pautam, principalmente, num ideal ético que deveria se perpetuar como condição de ordem e progresso social.

Por seu turno, a historiografia moderna retira do sujeito individual esse papel orientador, e em seu lugar emergem as leis científicas em sua neutralidade axiológica e racionalidade imanente. Bastaria então entender as determinações externas das condutas sociais para que pudéssemos conhecer os rumos inexoráveis de um suposto progresso. Estes deveriam ser simplesmente trazidos à luz, e assim poderiam orientar as ações humanas a partir de uma atitude empirista do sujeito do conhecimento em relação à história, agora tomada como um objeto tão passível de análise científica quanto o desenvolvimento de um organismo biológico.

O papel do indivíduo se manteve em grande medida em segundo plano, mesmo diante de uma definição mais precisa das especificidades das ciências históricas surgida com o desenvolvimento daquela historiografia moderna. As motivações subjetivas das ações humanas passariam a ser vistas como pouco significativas diante das relações materiais de produção, das estruturas simbólicas ou das condições linguísticas de exercício do poder, para ficarmos apenas nos exemplos mais expressivos. Recentemente, no entanto, o indivíduo tem sido retomado como objeto historiográfico significativo, e uma verdadeira "guinada subjetiva" pode ser percebida em discussões que vão da micro-história ao retorno da biografia. ${ }^{2}$

O presente artigo não pretende resolver esse problema metodológico mais amplo, e nem teria condições de fazê-lo. Todavia, acredito que a consideração de certas formas específicas de 
.continuação nota 2 ...

se institucionalizou como disciplina independente no século XIX. No entanto, gostaria de sugerir aqui alguns dos trabalhos que embasam essa reflexão inicial. Para uma análise topológica da história da historiografia, cf. KOSELLECK, Reinhart. Futuro passado: contribuição à semântica dos tempos históricos. Rio de Janeiro: Contraponto: Ed. PUC-Rio, 2006, RÜSEN, Jörn. Razão histórica: teoria da história: os fundamentos da ciência histórica. Brasília: Editora da Universidade de Brasília, 2001 e RÜSEN, Jörn. História viva: teoria da história: formas e funções do conhecimento histórico. Brasília: Editora da Universidade de Brasília, 2010. Sobre a mencionada "guinada subjetiva", cf. SARLO, Beatriz. Tempo passado: cultura da memória e guinada subjetiva. São Paulo: Companhia das Letras, 2007

3 Aqui proponho uma analogia à crítica feita por Pierre Bourdieu a Thomas Kuhn em BOURDIEU, Pierre. "O campo científico". In ORTIZ, Renato [org.]. Pierre Bourdieu: sociologia. São Paulo: Ática, 1983. Embora a discussão, nesse caso, gire em torno da história da ciência, acredito que uma crítica análoga seja pertinente também para as narrativas acerca da história intelectual brasileira que as encaram como espécies "sucessões paradigmáticas". A este respeito, conferir também HOCHMAN, Gilberto. "A ciência entre a comunidade e o mercado: leituras de Kuhn, Bourdieu, Latour e Knorr-Cetina". In PORTOCARRERO, Vera [org.]. Filosofia, história e sociologia das ciências I: abordagens contemporâneas. Rio de Janeiro: Editora FIOCRUZ, 1994

4 Sobre o contexto das instituições científicas brasileiras no século XIX, cf. SCHWARCZ, Lilia Moritz. Espetáculos das Raças: cientistas, instituições e questão racial no Brasil 1870-1930. São Paulo: Companhia das Letras, 1993. Para uma discussão mais ampla sobre a ciência e a técnica como ideologia, of. HABERMAS, Jürgen. Técnica e ciência como "ideologia". In Técnica e ciência como "ideologia". Lisboa: Edições 70, [1968]. ação individual pode nos ajudar a compreender melhor um problema historiográfico cada vez mais caro para o contexto brasileiro: as disputas em torno da definição de um ethos nacional por meio das práticas de proteção de seu patrimônio cultural. Desse modo, desejo demonstrar que as estratégias narrativas empreendidas por Luís Saia junto à regional paulista do órgão encarregado de conhecer e proteger o patrimônio histórico e artístico nacional, o atual IPHAN, nos fornecem elementos preciosos para repensarmos essa trajetória institucional.

Este é, no entanto, apenas um dos aspectos que nos têm permitido reconsiderar com um grau crescente de precisão o valor das ações empreendidas por Saia ao longo da sua diversificada carreira profissional. A contribuição deste artigo será, portanto, bastante modesta diante do potencial que o estudo da vida desse engenheiro-arquiteto paulista ainda tem a nos oferecer.

Este artigo se divide em quatro partes. Na primeira delas proporei uma interpretação alternativa a respeito dos primórdios das ações federais de proteção patrimonial por meio da institucionalização do Serviço do Patrimônio Histórico e Artístico Nacional (SPHAN), desejando destacar o papel a que então ficaram restritos os intelectuais paulistas neste campo, bem como o peso que as discussões advindas do campo antropológico tiveram nesse jogo. Na segunda parte tratarei da produção historiográfica empreendida por Luís Saia, demonstrando em que medida ela respondeu a uma série de exigências práticas ligadas a um projeto de construção da nação específico da intelectualidade paulista. Na terceira parte mostrarei como o sentido produzido pela narrativa historiográfica de Saia se efetivou, para além de outros tipos de ações, em práticas concretas de representação da especificidade paulista no conjunto dos bens culturais tombados pelo órgão federal. Por fim, apresentarei ao final uma reflexão a respeito das ressignificações que a obra do engenheiro-arquiteto paulista adquiriu após a sua morte em 1975 .

\section{Projetos regionais de nação e conflitos intelectuais: a emergência do SPHAN}

Um primeiro passo necessário para uma compreensão mais precisa do significado das ações de Luís Saia no interior das políticas nacionais de proteção ao patrimônio cultural é a desconstrução de um mito de origem. O Serviço do Patrimônio Histórico e Artístico Nacional não se originou simplesmente da união de um grupo coeso de intelectuais engajados de forma ascética em torno um ideal comum, representado por um amor difuso às coisas de nosso passado nacional. Uma análise mais cuidadosa das negociações que desaguaram no Decreto-Lei n 25 de 30 de novembro de 1937 não deixa dúvidas de que ele foi fruto de uma acirrada disputa por um recurso escasso: a proteção de projetos culturais específicos de nação por um Estado a partir de então bastante fortalecido.

A ideia de "fase heroica do IPHAN", criada pelo próprio Luís Saia (SAIA, 1977) e apropriada de forma acrítica por boa parte de nossa historiografia do patrimônio, passou a fornecer uma falsa ideia de unidade de projetos intelectuais. No entanto, mais plausível que a imagem de uma "comunidade intelectual" a partilhar uma espécie de "paradigma" a respeito do que poderia ser definido objetivamente como a identidade cultural da nação, creio que nos aproximaríamos mais da realidade vivida por esses sujeitos se utilizássemos a ideia de um "campo de batalha". ${ }^{3}$

Esse campo vinha sendo definido no Brasil desde o século XIX, sobretudo a partir da década de 1870, quando a nação passa a ser pensada de maneira cada vez mais autônoma pelos "homens de sciencia", numa especialização e institucionalização de saberes que coincidem com a complexificação do cenário político e social brasileiro. ${ }^{4}$ Assim, projetos de nação diversos, não necessariamente coincidentes, seja entre si ou com o projeto tradicional monárquico centrado na figura de d. Pedro II, passam a se expressar em saberes produzidos regionalmente, por meio de uma apropriação seletiva da ciência difundida a partir da Europa e com uma função bastante instrumental, sobretudo no que diz respeito à definição do espaço que as diferentes "raças" ocupariam no país projetado para o futuro. Lilia Moritz Schwarcz (1993) percebe este fenômeno dentro de um recorte temporal preciso, isto é, enquanto haveria durado um "paradigma de época", que toma força a partir de 1870 e entra em crise na década de 1930, quando finalmente as teorias raciais conheceriam um descrédito definitivo no meio 
5 Sobre o projeto de preservação dos monumentos históricos nacionais, surgido a partir da viagem a Minas Gerais realizada por Mário de Andrade, Olívia Guedes Penteado, Godofredo da Silva Teles, Tarsila do Amaral e Oswald de Andrade, cf. CALIL, Carlos Augusto Machado. "Sob o signo do Aleijadinho: Blaise Cendrars precursor do $\mathrm{Pa}-$ trimônio Histórico". In: ANDRADE, Antônio Luís Dias [et al.]. Patrimônio: atualizando o debate. São Paulo: 9a SR/ IPHAN, 2006.

6 Com relação ao processo de constituição da SEF, cf. AMOROSO, Marta. Sociedade de Etnografia e Folclore (1936-1939). "Modernismo e Antropologia". In: CENTRO DE CULTURA DE SÃO PAULO. Catálogo da Sociedade de Etnografia e Folclore. São Paulo, 1993. Disponível em <centrocultural.sp.gov.br/livros/ pdfs/sef.pdf>, ANDRADE, Mário de. Cartas de trabalho: Correspondências com Rodrigo Mello Franco de Andrade, 1936-1945. Brasília: Secretaria do Patrimônio Histórico e Artístico Nacional: Fundação Pró-Memória, 1981, RUBINO, Silvana. "A memória de Mário". Revista do Patrimônio Histórico e Artístico Nacional. [Brasília], n. 30, p. 138-155, 2002, e VALENTINI, Luísa. Um laboratório de antropologia: o encontro entre Mário de Andrade, Dina Dreyfus e Claude Lévi-Strauss (19351938). Dissertação (Mestrado em Antropologia Social). São Paulo: Programa de Pós-Graduação em Antropologia Social, FFLCH/USP, 2010

7 Evidência disso é a coleção "Etnographia Sertaneja", de Roquette-Pinto, e a colaboração de Torres com a Comissão Nacional do Folclore para o Congresso e exposição ocorridos na década de 1950, dentre outros projetos que posteriormente mencionaremos. Também podem ser encontradas outras evidências nesse sentido em DIAS, Carla da Costa; LIMA, Antônio Carlos de Souza. "O Museu Nacional e a construção do patrimônio histórico nacional. Revista do Patrimônio Histórico e Artístico Nacional, Brasília, n. 34, p. 199-222, 2012. científico. É necessário, no entanto, não simplificar em demasia esse momento de transformações, pois algumas dessas instituições nascidas no século XIX souberam se adaptar aos novos tempos. Refiro-me, em especial, ao Museu Nacional da Quinta da Boa Vista, no Rio de Janeiro.

\section{A SEF de Mário de Andrade versus o Museu Nacional de Heloisa Alberto Torres}

Não se pode desconsiderar o peso do campo antropológico em construção no país no que diz respeito à construção do SPHAN. Em 1924 já começava a se esboçar um interesse preservacionista num grupo constituído em torno da figura de Mário de Andrade. ${ }^{5}$ Posteriormente, em meados da década de 1930, essas preocupações se juntariam à necessidade de se conhecer cientificamente a cultura brasileira, o que se expressaria nos projetos folclóricos e etnográficos constituídos no interior do Departamento de Cultura da Cidade de São Paulo (DC) e, especificamente, na Sociedade de Etnografia e Cultura (SEF) dali surgida. ${ }^{6}$

Mas a institucionalização das práticas de proteção do patrimônio cultural nacional não foi incumbida diretamente à intelectualidade paulista. Com o sucesso político de Gustavo Capanema no governo Vargas (SCHWARTZMAN et al., 2000), a organização de um serviço de proteção patrimônio histórico e artístico nacional acabou ficando a cargo de um grupo de intelectuais mineiros que, antes mesmo do grupo paulista aqui mencionado, possuía seus próprios anseios preservacionistas, ancorados numa longa tradição de se considerar as cidades coloniais mineiras como uma espécie de "sacrário" da nação (BRAGA, 2010). Todavia, Rodrigo Mello Franco de Andrade, que ficou responsável por sua organização, não deixou de encomendar a Mário de Andrade o anteprojeto do Serviço.

Se o SPHAN não se tornou um órgão de antropólogos (ao menos durante suas primeiras gestões), o saber antropológico e etnográfico que se constituía naquele momento foi fundamental para compreendermos não só o formato tomado pela instituição, mas igualmente a forma pela qual o patrimônio arqueológico e etnográfico passou a ser ali protegido. O anteprojeto para o "Serviço do Patrimônio Artístico Nacional" de Mário de Andrade, produzido em
1936, propunha uma política museológica em que as ciências naturais deveriam se separar da etnografia, de acordo com uma compreensão específica do que se poderia considerar uma cultura autenticamente nacional. Essa acepção de "cultura brasileira" vinha sendo construída na SEF com base nas orientações de Dina Lévi-Strauss e do interesse folclorístico de Mário de Andrade. Isso significava buscar, registrar e analisar amplamente as manifestações culturais populares que pudessem indicar elementos de uma constituição autenticamente nacional. Esta acepção específica de cultura expressou-se no conceito ampliado de "arte" que se pode encontrar no anteprojeto de Mário de Andrade.

Foi ao explicitar tais pressupostos que, finalmente, os projetos de nação da intelectualidade paulista se chocaram com o dos naturalistas do Museu Nacional. Heloisa Alberto Torres, diretora do Museu Nacional entre os anos de 1937 e 1955, considerava, em primeiro lugar, os estudos culturais como ramo específico da biologia, e o homem não poderia ser corretamente compreendido se, para além de aspectos socioculturais, não fossem considerados os mesológicos e fisiológicos. Em segundo lugar, embora no Museu Nacional não se descurasse do que então se denominava "cultura popular"7, considerava-se a preservação das culturas indígenas muito mais urgente, tanto por causa de sua rápida extinção, sobretudo pelo pouco preparo tecnológico para o enfrentamento do elemento "civilizado", quanto pelo fato de representarem culturas num estágio "primitivo" de desenvolvimento, portanto um patrimônio mais valioso do ponto de vista de uma ciência ainda marcadamente evolucionista.

Até este momento não se poderia notar a existência de qualquer espécie de conflito entre Mário de Andrade e Heloisa Alberto Torres. Mas, ao perceber as implicações do anteprojeto de Mário de Andrade, Rodrigo Mello Franco de Andrade decide antes colher as impressões da diretora do Museu Nacional, que responde de forma indignada ao anteprojeto, causando, em contrapartida, o ressentimento do intelectual paulista.

Na carta em que Torres responde a Mello Franco de Andrade sobre o anteprojeto, ela se coloca na ofensiva, e deixa claro, primeiramente, que não abrirá mão da posição conquistada pelo Museu: 
8 O Museu Nacional foi criado em 1818, por decreto de d. João VI.

9 Arquivo Central do IPHAN, RJ, Pasta Personalidades. TORRES, Heloísa Alberto. AA02/M003/P01/Cx. 0125/ P. 0404. De fato, o Palácio da Quinta da Boa Vista foi tombado em 1938
Admitamos que se pudesse remediar a todos esses inconvenientes [trazidos pelo projeto de Mário e expostos à Mello Franco de Andrade nesta carta] creando o 'Serviço do Patrimônio Artístico, Histórico e Antropológico Nacional', e instalado em edifício anexo ao ou próximo do Museu de História Natural, ainda surgem considerações muito ponderàveis. Uma, de natureza tradicionalística, não pode deixar de ser tomada em conta no momento em que se pretende organizar a defesa do patrimônio histórico do Brasil: é o golpe desferido a uma instituição de 118 anos de existência ${ }^{8}$ e que, máu grado a incomprensão de suas finalidades, pela maioria dos Governos, tem conseguido levar e manter em alto nível o nome do Brasil por todo mundo, na divulgação do que a nossa terra tem de mais belo: a sua natureza e a sua gente. A organização desses trabalhos de defesa não pode ser iniciada pela mutilação de um instituto centenário e glorioso, quando um dos primeiros monumentos nacionais a serem tombados pelo Serviço projectado devería ser certamente o Museu Nacional [grifos da autora]. ${ }^{9}$

No entanto, Torres sugere uma forma de colaboração entre as duas instituições:

Penso que se poderia estabelecer uma colaboração estreita entre a Secção de Etnografia do Museu Nacional e o 'Serviço', uma verdadeira articulação entre as duas entidades e da qual poderia resultar benefício consideràvel para êste sem prejuizo dos trabalhos que aquela levasse a efeito. Todo o material de etnografia constaria do tombamento, os técnicos do Museu Nacional colaborariam no Conselho Consultivo da S.P.A.N., organizariam relações de jazidas etnográficas a serem tombadas, levantariam mapas com a distribuição geográfica dos monumentos a serem protegidos, elaborariam monografias a serem publicadas pela S.P.A.N.

Por seu lado a S.P.A.N. providenciaria melhores condições para o desenvolvimento dos trabalhos da Secção de Etnografia do Museu Nacional.

Por seu lado a S.P.A.N. providenciaria melhores condições para o desenvolvimento dos trabalhos da Secção de Etnografia do Museu Nacional.

O que teria levado Rodrigo Mello Franco de Andrade a optar pela proposta de Torres e não pela de Mário de Andrade? Essa resposta passa pela compreensão da forma pela qual os intelectuais envolvidos se estruturavam, naquele momento, em redes sociais.

Mello Franco de Andrade deparou-se, já em 1937, com quatro "cliques" mais importantes interessados no que o futuro SPHAN poderia oferecer: o seu próprio grupo de modernistas mineiros, interessados na proteção da arte e arquitetura colonial brasileira, sobretudo a mineira e religiosa; o grupo de arquitetos modernos que haviam se aproximado de Capanema via projeto do edifício do MESP; a intelectualidade paulista, que desejava ampliar ao nível nacional seus projetos culturais; e o Museu Nacional, que desde a década de 1920 ansiava pelo apoio mais efetivo do governo federal no que tange à proteção de sítios arqueológicos e do patrimônio biológico e antropológico do país.

Postas as cartas na mesa, Mello Franco de Andrade possuía três alternativas: 1) propor uma política com ênfase no patrimônio arquitetônico, o que agradaria arquitetos modernos e modernistas mineiros; 2) contemplar a proposta de proteção do patrimônio arqueológico e etnográfico do Museu Nacional; 3) acatar o projeto amplo de Mário de Andrade. Os projetos "1" e "2" poderiam coexistir, e Mello Franco teria apoio de seus correligionários mineiros, dos arquitetos modernos e do Museu Nacional; mas a adoção de "3" pressuporia desagradar todos os outros grupos para contar com o apoio apenas dos paulistas, que, além de tudo, haviam participado ativamente do movimento de 1932 (tanto Mário de Andrade quanto Luís Saia se alistaram para os combates armados). Na verdade, Mello Franco dispunha então de apenas duas alternativas.

Desse modo, mesmo que todos os grupos estivessem em pé de igualdade no que tange aos laços manipuláveis e aos recursos a disposição, teríamos uma situação que claramente penderia a favor do Museu Nacional nessa disputa específica com o grupo de Mário de Andrade. Mas este não era o caso: todos os grupos eram vistos com simpatia por Vargas, com exceção do grupo de Mário, que se ligava a interesses políticos diametralmente opostos aos do governo federal; enquanto Torres estava inserida em outras instituições federais mais antigas e consistentemente 
compostas por outras redes políticas e intelectuais, Mário de Andrade se ligava a instituições criadas em São Paulo em meados da década de 1930.

O pedido formal de cooperação ao Museu Nacional viria em ofício datado de 24 de fevereiro de 1938, escrito por Mello Franco de Andrade e endereçado à Heloisa Alberto Torres:

Havendo necessidade de essa repartição prosseguir nos trabalhos iniciados, sob a vossa orientação pessoal, com o objetivo de proceder ao tombamento dos bens de excepcional valor arqueológico e etnográfico existente no país e bem assim de adotar as medidas convenientes para a localização e proteção dos achadouros do material daquela natureza, venho consultar-vos sobre a possibilidade de, na forma do disposto no art. 25 do decreto-lei n. 25, de 30 de novembro de 1937, o Serviço do Patrimônio Histórico e Artístico Nacional obter a cooperação do Museu Nacional para o fim da secção de antropologia e etnografia desse estabelecimento tomar a si a execução da referida tarefa. Na hipótese de resposta favorável à presente consulta, esta diretoria delegará a mencionada secção do Museu Nacional os poderes que Ihe foram atribuídos pelo dito decreto-lei para o efeito desejado, correndo as despesas que se tiverem de realizar com os trabalhos em apreço por conta das dotações consignadas no vigente orçamento ao Serviço do Patrimônio Histórico e Artístico Nacional. Quanto à elaboração

10 Apud. DIAS, op. cit., 2012 , p. 206.

11 Além dos quatro mencionados, compuseram esta reunião os seguintes inteectuais: Gustavo Capanema (que presidiu apenas esta reunião inaugural, não mais participando do Conselho), Otávio José Correia Lima, Augusto José Marques Júnior, Manuel Bandeira, Rodolfo Gonçalves Siqueira, Francisco Marques dos Santos, Carlos de Azevedo Leão, Rodrigo Mello Franco de Andrade, Gustavo Barroso, Osvaldo Teixeira e Afonso Arinos de Mello Franco. Esta composição se modificaria esporadicamente e de forma lenta ao longo dos anos, sobretudo em função do caráter vitalício do Conselho. Sobre as rajetórias individuais desses intelectuais e sobre este órgão deliberativo, consultar CHUVA, op. cit., 2008. do programa a ser realizado durante o ano corrente no tocante às questões de arqueologia, etnografia e arte popular, deverá ser assentado mediante proposta que vos dignardes apresentar a esta diretoria logo que vos parecer oportuno. ${ }^{10}$

Rodrigo Mello Franco de Andrade justifica sua opção da seguinte forma ao poeta paulista, em carta que Ihe foi dirigida dia $1^{\circ}$ de agosto de 1936, não deixando dúvidas quanto a correlação de forças do campo intelectual brasileiro naquela conjuntura:

Achei procedente tudo quanto Você me escreveu a respeito da carta de dona Heloísa. Sucedeu até que alguns dos seus argumentos já tinham sido invocados por mim, quando discuti com ela a questão. Mas eu estava muito incapaz naquele dia e oprimido por uma dificuldade de expressão maior ainda que a do costume. Fui seduzido com facilidade, embora [tivesse] saído ainda convencido das vantagens que resultariam da adoção do ponto de vista que Você sustentara. Como, porém, me pareceu impraticável organizar um museu de arqueologia, etnografia e arte popular com a oposição intransigente de todo o pessoal do Museu Nacional, tive de me conformar com a inclusão apenas de um dispositivo no projeto prevendo para o futuro a realização do empreendimento, a fim de contar assim com a cooperação de dona Heloísa, quer para o tombamento do material reunido na Quinta da Boa Vista, quer para o tombamento geral.

De resto, confesso a Você que fiquei intimidado diante da responsabilidade de desmembrar do museu existente as coleções que nos interessavam. Aquilo, tal como está organizado, tem sempre produzido alguma coisa de apreciável. É uma instituição centenária que merece ser tratada com uma consideração especial. Se a gente insistisse em reformá-la agora de acordo com o seu projeto, seria tido, por dona Heloísa e pelos especialistas mais capazes de lá, como inimigo. Com que elementos poderíamos contar para suprir a falta de cooperação do pessoal melhor do Museu Nacional? Pelo menos, graças ao adiamento da reforma, captamos as boas disposições da própria dona Heloísa, cuja colaboração é preciosa. Mais para adiante, veremos o que será possivel conseguir naquele sentido (ANDRADE, 1987, p. 120)

Já na reunião de 9 de maio de 1938, quando se instituíram as formas de funcionamento do Conselho Consultivo do SPHAN, estavam presentes nada menos que quatro representantes do $\mathrm{Mu}$ seu Nacional (de longe a instituição mais bem representada) e que permaneceriam por décadas na composição deste órgão deliberativo: EdgardRoquette Pinto, Alberto Childe, Raimundo Lopes e a própria Heloisa Alberto Torres, na condição de dirigente de um dos museus nacionais. ${ }^{11} \mathrm{~A}$ diretora do Museu Nacional conquistava, assim, mais um território para sua já vasta atuação e para a representação de seus projetos culturais. A proteção do patrimônio arqueológico e etnográfico brasileiro ficava quase que diretamente a cargo do próprio Museu Nacional (SIMÃO, 2008; DIAS, 2014; LOWANDE, 2014), enquanto que o SPHAN se dedicaria, sobretudo, à proteção do patrimônio arquitetônico. 


\section{A redefinição das estratégias: Luís Saia e a história da morada paulista}

\author{
Os primeiros trabalhos de Luís Saia em \\ parceria com Mário de Andrade
}

A partir de 1938 o projeto folclórico e etnográfico de Mário de Andrade é sistematicamente desmontado.

12 O processo de negociação que conduziu Mário de Andrade à frente do SPHAN no estado de São Paulo encontra-se descrito nas correspondências trocadas entre ele e Rodrigo Melo Franco em ANDRADE, 1981 e ANDRADE, 1987

13 Havia organizado em 1936 o Curso de Etnografia e Folclore, aproveitando a presença do casal Lévi-Strauss no Brasil e incumbindo Dina, então esposa de Claude, de sua organização; criado a Sociedade de Etnografia e Folclore, que contaria com a colaboração dos etnógrafos e folcloristas "práticos" formados nesse mesmo curso (dentre eles Luís Saia), além de outros etnólogos e antropólogos já amplamente reconhecidos no meio intelectual brasileiro; implementado uma série de Parques Infantis, que possuíam fins tanto educativos quanto etnográficos, pois que também objetivavam a coleta de dados físicos e culturais (especialmente linguísticos) a serem obtidos por meio do estudo dos filhos dos operários pobres dos bairros de São Paulo; planejado as "Casas de Cultura", que se localizariam nos bairros operários paulistanos e visariam a difusão da cultura nacional por meio de bibliotecas e outras atividades culturais; por fim, Mário de Andrade organizou coordenou uma série de pesquisas folclóricas e etnográficas nos arredores da capital paulista, publicadas no Boletim da SEF, na Revista do Arquivo Municipal e apresentados no Congresso da Língua Nacional Cantada, realizado também em 1937 e organizado por ele próprio.

14 "Artigos irão dia 30 [de junho de 1937]. Um só histórico Nuto Sant'Anna. Outro, um estudo sobre igreja $S$. Antônio, com engenharia dentro, feito por mim e Luiz Saia" (ANDRADE, op. cit., 1981, p. 73).
Um motivo significativo, mas nunca mencionado, que concorreu para essa derrocada foi sem dúvida o resultado da disputa acima narrada. Outro motivo, externo ao campo etnográfico, relaciona-se mais diretamente aos efeitos da implantação do Estado Novo no estado de São Paulo. A Missão de Pesquisas Folclóricas, realizada naquele ano pelo Departamento de Cultura de São Paulo, representava inicialmente uma promessa de, enfim, levar a cabo um projeto acalentado por Mário de Andrade desde fins da década de 1920, quando realizou as viagens, relatadas em $O$ turista aprendiz, de coleta sistemática de elementos do folclore brasileiro dispersos pelas regiões Norte e Nordeste do país e que pudessem proporcionar o estudo e compreensão das raízes culturais da nacionalidade. A forma abrupta pela qual essa mesma Missão foi interrompida, quando Saia, que a liderava, o maestro Martin Braunwieser, Benedito Pacheco e Antônio Ladeira encontravam-se já em Belém do Pará (CARLINI, 1994), expressa de modo emblemático, por outro lado, a interrupção de um projeto que significou para Mário de Andrade, segundo relato de Paulo Duarte, amigo próximo seu, o início de um longo e doloroso processo de desinteresse pela própria vida (DUARTE, 1971). A substituição de Fábio Prado na prefeitura de São Paulo, em 1938, pela interventoria de Prestes Maia (mais preocupado com a construção de avenidas do que com políticas culturais) selou o destino do Departamento de Cultura, agora dirigido por Francisco Pati e cada vez mais enfraquecido.

Antes disso, no entanto, já em 1937 (portanto depois da disputa travada com Heloisa Alberto Torres), Mário de Andrade foi incumbido por Rodrigo Melo Franco da "assistência técnica" da 6a região do recém-fundado SPHAN (que corresponderia aos estados de São Paulo, Paraná, Santa Catarina e Rio Grande do Sul), isso quando o polígrafo paulista encontrava-se no auge do entusiasmo em relação ao trabalho desenvolvido no Departamento de Cultura da Municipalidade de São Paulo. ${ }^{12}$ Mário de Andrade vinha realizando diversas atividades no órgão municipal, ${ }^{13}$ motivo pelo qual recusou por várias vezes aceitar a incumbência que the foi dada por Rodrigo Melo Franco. O intelectual paulista sugeriu o nome de seu amigo Paulo Duarte para esse cargo, pois que o mesmo estava naquele momento engajado numa campanha pela proteção do patrimônio cultural brasileiro e pela institucionalização de um órgão estadual (na verdade um projeto que almejava expandir-se para o todo nacional) nos moldes do que veio a se tornar o SPHAN; contudo, essa indicação obviamente não se efetivaria, dada a ativa participação do deputado liberal paulista no movimento armado de 1932 (DUARTE, 1971). Por fim, impedido de acumular o cargo de assistente técnico do SPHAN com a direção do Departamento de Cultura, Mário de Andrade sugeriu o nome de Luís Saia, aceito finalmente, com alguma desconfiança de Rodrigo Melo, para conduzir os trabalhos da regional paulista.

Durante todo esse conturbado período, Mário de Andrade e Luís Saia trabalharam juntos nos primeiros levantamentos daquilo que, do ponto de vista arquitetônico, seria digno da proteção do SPHAN (pois já vimos que a tutela do patrimônio arqueológico e etnográfico foi informalmente monopolizada pelo Museu Nacional). A confiança de Mário de Andrade em relação a Luís Saia expressava-se tanto na forma como o primeiro se referia ao último em algumas de suas correspondências (ANDRADE, 1981) como nas responsabilidades que the atribuiu nesses anos de trabalho conjunto. Prova maior disso é o fato de Saia ter sido escolhido para chefiar a Missão de 1938, expedição que havia muitos anos o próprio Mário sonhava em realizar (CARLINI, 1994). Por isso é difícil afirmar com segurança onde terminaria a contribuição intelectual de um e começaria a do outro neste período e no que se refere à definição do patrimônio histórico e artístico do estado de São Paulo. Saia, por exemplo, teria participado da elaboração do "Anteprojeto do SPAN"; o próprio Mário de Andrade comenta que o artigo que publicou com o seu nome no primeiro número da Revista do SPHAN deve ser atribuída a Saia (ANDRADE, 1981). ${ }^{14}$ Por fim, do respeito intelectual de Mário de Andrade em relação a Luís Saia não restam dúvidas, haja vista o ressentimento do primeiro quando, após ter escrito uma primeira versão do trabalho sobre o Padre Jesuíno do Monte Carmelo (do qual foi incumbido pelo SPHAN no início da década de 1940), ficou profundamente ressentido por causa 
das críticas que lhe fez o seu amigo engenheiroarquiteto, demonstrando desse modo, acima de qualquer outra coisa, respeito por sua opinião (ANDRADE, 1981).

Mário de Andrade, Luís Saia, Nuto Sant'Anna e Hermann Graesser (o "Germano") começaram, então, em 1937, a inventariar a arquitetura paulista passível de futuros tombamentos. Uma vez mais o projeto de nação da intelectualidade paulista se via, no entanto, ameaçado por uma espécie de "sub-representação", pois que as igrejas e as "casas velhas" arroladas no primeiro relatório enviado por Mário de Andrade ao núcleo dirigente do SPHAN no Rio de Janeiro mostrava uma série de edifícios pouco interessantes do ponto de vista da tipologia técnica e estética de uma arquitetura previamente definida como representativa da identidade nacional. Em outras palavras, as construções paulistas não se comparavam, conforme constatava um desanimado Mário de Andrade, à beleza das igrejas mineiras, bahianas e pernambucanas. No entanto, já se imaginava uma alternativa: "a orientação paulista tem de se adaptar ao meio: primando a preocupação histórica à estética" (ANDRADE, 1981, p. 69).

Mário de Andrade deixou, nesse ponto, um projeto inacabado. Contribuiu, por certo, com as discussões que produziram um "tipo arquitetônico" representativo da cultura bandeirista, pois o contato com as "casas velhas" paulistas arroladas em seu relatório e o estudo pormenorizado da residência do Sítio Santo Antônio, em São Roque, já permitiriam as constatações que seriam levadas adiante por Luís Saia. O que tentarei mostrar a seguir é que, após o falecimento de Mário de Andrade em 1945, foi a produção historiográfica empreendida por Luís Saia e os efeitos que ela pôde produzir nas práticas preservacionistas paulistas que permitiram sustentar e mesmo aprofundar a representatividade do estado de São Paulo no interior de uma noção mais abrangente de identidade nacional. Além disso, sobretudo a partir da década de 1950, elas contribuíram com a emergência de novos critérios para a tutela do patrimônio cultural nacional que acabaram se estabelecendo a partir da década de 1970. No entanto, o principal objetivo será mostrar que a existência dessa margem de ação no interior do órgão nacional permitirá repensar as formas pelas quais a história das políticas de tutela do patrimônio cultural da nação tem sido narrada historiograficamente.

\section{Morada paulista}

O livro Morada paulista, organizado por Luís Saia em 1972, nos oferece bons indícios para a compreensão das ações empreendidas pelo SPHAN entre 1945 e 1975, e mesmo para entendermos melhor algumas modificações mais amplas ocorridas nas práticas de proteção ao patrimônio cultural brasileiro. Todavia, esse caminho requer alguns cuidados.

Morada paulista nos fornece um sentido bastante amplo para a evolução da arquitetura regional paulista. Obra de um Luís Saia já maduro, pode ser lida como uma tentativa do arquiteto de conferir sentido às ações da regional paulista do SPHAN sob a sua direção e, ao mesmo tempo, à suas próprias ações individuais. Esse tipo de produção narrativa pode ser tomado como uma característica marcante do IPHAN ao longo de sua trajetória, e se prende à construção de uma identidade institucional buscada no intuito de orientar as condutas de seus funcionários em momentos de "crise de sentido". Isso aconteceu de forma bastante clara com a morte de Rodrigo Melo Franco de Andrade, com a posse de Aloísio Magalhães e sua morte prematura e também após o desmonte do órgão durante o governo Collor (LOWANDE, 2013).

E qual seria a "crise de sentido" que conduziu Saia a publicar esse livro fundamental para a história da arquitetura brasileira? Para isso é possível apenas aventar algumas hipóteses, que apresentarei, contudo, apenas ao final desse artigo. Por ora, a consideração do momento em que o livro foi produzido visa nos alertar para o fato de que, em primeiro lugar, não é possível julgar o conjunto das ações realizadas pelo arquiteto à luz do sentido mais amplo fornecido em Morada paulista, pois as obras de restauração e mesmo historiográficas empreendidas entre fins da década de 1930 e primeira metade da década de 1940 certamente não levaram em consideração outros aspectos a respeito dos quais Saia passou a ter consciência efetiva mais tardiamente. Por outro lado, não se pode julgar também o amplo rol de ações levadas a cabo por Saia apenas tendo em mente algumas restaurações por ele empreendidas, pois isso representaria ignorar uma série de outras ações igualmente significativas (inclusive na área da proteção ao patrimônio cultural), que não podem ser compreendidas apenas com base em suas teorizações a respeito da casa bandeirista, 
pois estas compõem somente parte do fenômeno mais amplo que denominou morada paulista.

De acordo com o próprio Luís Saia, a ideia para a organização do livro Morada paulista partiu de uma série de artigos publicados na revista Acrópole, em 1956, sobre a "evolução da arquitetura residencial paulista" ("Arquitetura de circunstância", "Intermezzo roceiro", "Economia de sobremesa" e "Ciclo ferroviário"). Segundo ele, "nessa época estava empenhado em recolocar certos problemas de planejamento, armando cursos de extensão, elaborando projetos de lei sobre reforma urbana e organizando a Comissão de Planejamento do IAB de São Paulo" (SAIA, 2005, p. 7). Somados aos artigos sobre geologia, pedologia e edafologia, aqueles artigos foram republicados pela Acrópole sob o título "Notas sobre revolução da morada paulista".

Morada paulista foi então organizado a partir daquelas "Notas", com o acréscimo de outros textos sobre a mesma temática. Selecionados os artigos (escritos entre 1945 e 1963), o livro foi então dividido em duas partes: "Notas sobre a evolução da morada paulista" (suprime-se o " $r$ " de revolução) e "Notas relacionadas com a tetônica demográfica de São Paulo". Antecedendo os trabalhos reunidos na primeira parte do livro, Saia escreve uma "Nota prévia", de grande valor para a interpretação de sua postura na escrita dos artigos ordenados em seguida, tendo sido certamente elaborado por ocasião da publicação do livro. Nele o significado da arquitetura paulista é contraposto ao da arquitetura oitocentista mineira e baiana e, além disso, explicitam-se os tipos de fonte utilizados, apontando sua validade e limitações.

O próximo capítulo, intitulado "Quadro geral dos monumentos paulistas", refere-se a uma palestra "destinada a divulgar os esforços no sentido de proteção do patrimônio histórico e artístico de São Paulo" (SAIA, 2005, p. 8). Esse capítulo funciona, no livro, como uma consideração "preliminar" de cunho teórico, na qual são expostos os períodos da evolução regional paulista bem como as "teses" principais e ancilares de cada um deles, além daquelas teses ou hipóteses (a que chama de "negadas") que foram preteridas em detrimento de soluções mais recomendadas ao modo de vida que se instalou no planalto paulista. Esse capítulo é de suma importância para a compreensão da forma como Saia atribui sentido para sua narrativa, ou seja, para a compreensão daquilo que aqui estou chamando de ideia de evolução regional da arquitetura paulista. Para exemplificar o quadro proposto por Luís Saia, talvez seja útil a elaboração de uma tabela (Tabela 1).

\section{A evolução regional paulista: arquitetura e sentido histórico}

Com base nessa síntese do que Saia considera a evolução da implantação populacional no estado de São Paulo, logo se depreende que ele foi além da definição tipológica daquilo que corresponderia à arquitetura bandeirista. A interpretação que ele produz para essa evolução se prende a uma análise das relações materiais de produção do paulista ao longo da história brasileira, com especial consideração do relacionamento deste tipo social com o meio e de modo a demonstrar, via arquitetura e implantação urbana, em que medida a cultura paulista (entendida certamente como o conjunto das objetivações de um modo de vida específico e em contínua transformação no tempo) seria significativa para a compreensão da cultura brasileira mais ampla. Têm-se, portanto, uma valoração da obra cultural paulista tanto por sua singularidade como por suas conexões indispensáveis com a formação da própria cultura nacional. É neste ponto, a meu ver que a obra de Luís Saia completa e mesmo supera as limitações iniciais do projeto cultural paulista no interior das políticas federais de cultura: ao longo do trabalho da regional paulista do IPHAN produz-se um sentido bastante eficaz para o conjunto das manifestações culturais paulistas. A crise de sentido a que se responde é, portanto, um problema identitário em relação ao qual os intelectuais paulistas se viam preteridos diante da ideia de nacionalidade hegemônica produzida a partir da década de 1930.

E como Luís Saia opera com a "tradição", isto é, o conjunto de experiências que funcionam como "componente intencional prévio do agir, que vem do passado para o presente e influencia as perspectivas de futuro no âmbito da orientação da vida prática atual"? (RÜSEN, 2001, p. 76). Esse caldo de experiências não pode, por si só, orientar condutas. É necessário, primeiramente, que estas experiências possam ser consideradas verdadeiras, sejam elas equivocadas ou acertadas, ou seja, devem possuir uma "pertinência empírica". Por 


Periodo
Primeiro período:
1500-1554

Segundo periodo:
1554-1611
(ano do estabelecimento de
Parnaíba e Mogi das Cruzes)
Terceiro periodo:
1611-1727: "se inicia quando
surgem resultados das
dissensões entre colonos e
quando alguns destes de
estabelecem de modo a criar os
novos pontos focais da gente
paulista"(p.27)

Quarto período: $1727-1765$ (restauração da capitania com o

Morgado de Mateus)
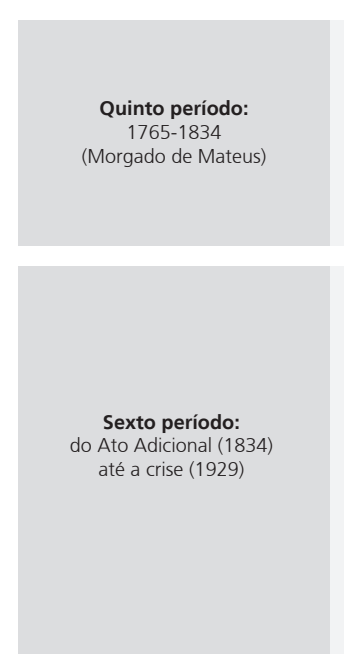

Conjunto das instalações que resultara desta fase da formação paulista, como documentário mais decisivo desta época (ausência de monumentos característicos); existência de "uma ou outra peça" que, "quer pela singularidade do seu valor arquitetonico, quer pelo significado histórico eventualmente expresso", merec uma "atenção especial"
Habitações da classe dirigente (solução mestiça tendo a faixa fronteira como principal Habitações do litoral norte de São Paulo (

Construções e instalações que, de soluções abstratas impostas ao sabor das circunstâncias (...) marcadas pela insubstância
que procede da probreza e da que procede da pr.
dependência". marcadas pela insubstância
Negação do binário "urbano rural" (domínio das teses colonas sobre as teses jesuíticas).
Teses ancilares

Exploração mercantilista (tese negada pelas condições topográficas e pedológicas do litoral santista) - "Toda a ação se realiza como um fenômeno de impacto ente a coisa europeia e

a) penetração territorial (guerra e conquista à europeia);

b) sediação simbólica de São Paulo no planalto (influência indígena).
Ação dessacralizadora, "fundada na montagem de uma estrutura social de caráter feudal-militar". Tese negada: "A teoria do baluarte cercado, destinado a explicitar o sentido aposseador da colonização portuguesa, se opôs a solução biológiça prática e o sa, se opôs a soluçáo biologica prática e o
retorno às formas já obsolecentes do feudalisretorno às formas já obsolecentes do feudalismo e da
$(28-90)$.
Distribuição dos colonos por um território relativamente vasto, em forma concêntrica e a partir do "centro" (Piratininga), com um raio de aproximadamente $50 \mathrm{~km}$.
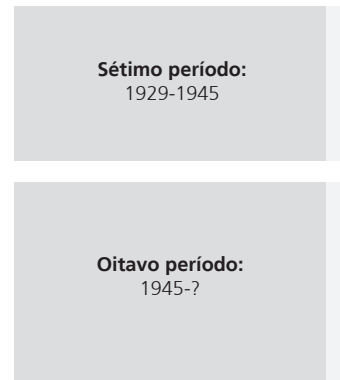

De um lado, representa a "relativa vitalidade surgida com a restauração da Capitania e como decorrência das pretensões militaristas do Morgado de Mateus", de outro, "fim ralo sopro longínquo das idéias que varriam o pensamento europeu, desobstruindo-o das formas estruturais medievais e preparando-o para o amadurecimento do capitalismo e advento do imperialismo".
Falta de uma propositura econômica "capaz de dar-lhe individualidade definida e própria, com temática autônoma e diretrizes próprias de desenvolvimento".
Instituição do binário urbano/rural, "sob o qual se efetuou a ocupação territorial, demográfica e econômica, de São Paulo.
Elevado número de pessoas exigido pela técnica tradicional de cultura, beneficiamento, transporte e comercialização do café: a) conquista territorial por faixas sucessivas e a cultura extensiva; b) distribuiçăa das cidades em rosários estendidos ao das cidades em rosários estendidos ao longo dos espigóes, c) rede ferroviaria em forma dastrica, d) formaçăo de zonas centraliza das em cidades-chave; e) hipodamização do traçado urbano; f) tratamento artesanal dos problemas técnicos: 1. condicionamento das soluçôes de equipamento às formas de implantação urbana adotadas; 2 . monopólio dos serviços públicos

a) policultura, seguida das primeiras tentativas de regionalização da produção; b) transformação das estruturas urbanas e
superação do traçado hipodâmico; c) superação do traçado hipodâmico; c)
estouro da organização dos serviços públicos; d) industrialização.

a) implantaçăo de um sistema industrial partir da base metropolitana (nova negação do binômio urbano-rural); b) complementação do esquema viário; c) explicitaçăo do zoneamento funcional; d) tratamento tecnológico dos problemas de equipamento urbano
regional; e) planejamento urbano e regional.

Tabela 1: Esquema de periodização utilizado por Luís Saia.

Montagem de uma nova estrutura econômico-social, baseada na industrialização. 
outro lado, é preciso também que tais experiências sejam recolhidas a partir de um significado imputado subjetivamente (o que, no caso da obra em questão, relaciona-se com o que Saia considerou importante para a prática arquitetônica em seus variados nichos), algo que se pode chamar de "pertinência axiológica". Por fim, para orientar eficazmente a ação dos "indivíduos alvo", no caso todos os atores, principalmente arquitetos e urbanistas, ligados às práticas preservacionistas e projetivas, isso tudo deve ser narrado de modo que "faça sentido".

\section{Os vestígios}

A pertinência empírica da história da arquitetura paulista narrada por Luís Saia se assenta numa espécie de "método de prospecção arqueológica" da arquitetura tradicional paulista. Diante de casas que antes eram valorizadas apenas por sua "ancianidade", Saia empreendeu uma espécie de "exegese construtiva" de cunho estratigráfico que cuidadosamente ia revelando as motivações técnicas e culturais de um modo de se construir casas próprios de um espaço e um tempo específicos. Tratava-se, portanto, muito menos de um a priori teórico a conduzir suas restaurações do que hipóteses fornecidas por uma leitura metódica dos monu-mentos arquitetônicos a partir das suas entranhas. ${ }^{15}$ Esse tipo de prática, metodicamente registrada nos cadernos de obra legados por Luís Saia, produziram as "inscrições" (LATOUR et al., 1997) necessárias para os enunciados narrativos que ele produziu acerca das especificidades arquitetônicas e, por conseguintes, culturais dos brasileiros piratininganos. Trata-se, portanto, de uma narrativa fortemente amparada na materialidade, condição indispensável para que um produto historiográfico seja percebido como válido, pois

as histórias convencem seus destinatários da credibilidade de seus conteúdos na medida em que demonstram o que foi o caso, no passado, por recurso aos vestígios ainda presentes desse mesmo passado. Dessa forma, quem quiser saber como as coisas aconteceram poderá convencer-se de que assim foi como está sendo dito. Para reforçar sua pertinência empírica, as histórias podem remeter a uma instância de autenticação. Essa instância consiste na contemporaneidade factual do passado, ou seja, no fato de que subsiste algo dele e que dá testemunho dele. As pretensões de validade suscitadas pelas histórias com relação a seus conteúdos empíricos são fundamentadas, destarte, com a operação tipicamente histórica da validação (RÜSEN, 2001, p. 100-101).

Não somente Luís Saia, mas toda a atuação do IPHAN caracteriza-se justamente por produzir uma "instância de autenticação" para uma série de narrativas sobre nacionalidade, fossem elas produzidas por modernistas mineiros (arquitetura civil e religiosa "barroca"), por antropólogos (patrimônio arqueológico e etnográfico) ou arquitetos modernos (arquitetura brasileira dotada de "equilíbrio" e "sobriedade", ligada universalmente a uma estética harmoniosa de raízes mediterrâneas e, sobretudo, não relacionada às impurezas estéticas produzidas pelo "ecletismo"16). O que Saia logrou, portanto, com sua produção historiográfica, foi garantir que o estado de São Paulo fosse representado no interior da ideia de nacionalidade então em produção graças a um texto histórico solidamente amparado na materialidade das residências que tombou, consolidou e restaurou.

\section{Os valores}

Ainda segundo Rüsen, "são normativamente pertinentes as histórias que [...] fundamentam o significado do passado, no presente, com normas que estão na base das intenções determinantes do agir de seus destinatários" (RÜSEN, 2001, p. 108). $A$ respeito disso é importante que observemos três momentos distintos na trajetória de Luiz Saia.

O primeiro deles se relaciona à sua adesão ao integralismo, entre 1932 e fins da década de 1930. Em 1932 Saia foi admitido na Escola Politécnica do Estado de São Paulo e, ao mesmo tempo, participava, ao lado de Ernani Silva Bruno (ambos se tornariam membros, mais adiante, da Sociedade de Etnologia e Folclore) da "Assembleia de Fundação da Sociedade de Estudos Políticos", realizada no dia 12 de março de 1932. Saia, então com 21 anos, ouviu um discurso proferido por Plínio Salgado, no qual exortava os que estavam ali presentes a "estudar os problemas nacionais" e traçar, "em consequência desses estudos, os rumos definitivos de uma política salvadora". ${ }^{17} \mathrm{O}$ "Manisfesto de outubro" pregava, dentre outras coisas, a luta contra a influência estrangeira, considerando brasileiras todas as origens étnicas encontráveis no território 
18 Dois anos depois esse e uma série de outros depoimentos, que saíram no jornal O Estado de S. Paulo sob o título Plataforma da nova geração, foram publicados, com o mesmo nome, pelo historiador Mário Neme. (NEME, Mário [org.]. Plataforma da Nova Geração. Porto Alegre: Globo, 1945).

19 A respeito das atividades de Luís Saia no campo do planejamento urbano, cf. MOTA, Juliana Costa. Planos diretores de Goiânia, década de 60: a inserção dos arquitetos Luís Saia e Jorge Wilheim no campo do planejamento urbano. Dissertação (Mestrado em Engenharia). - Escola de Engenharia de São Carlos, Universidade de São Paulo, 2004. No que diz respeito à docência, Saia coordenou, em 1974, juntamente com o próprio Reis Filho e Ulpiano Bezerra de Menezes, o "Curso de Especialização em Conservação de Monumentos e Conjuntos Históricos", promovido pelo IPHAN em parceria com - CONDEPHAAT e a USP. Muito embora Reis Filho relate que Saia nunca tenha lecionado na FAU como professor dos quadros da USP, Ficher afirma que, em 1951 , o engenheiro-arquiteto foi professor da cadeira "Arquitetura no Brasil" e, em 1955, "realizou uma prova de títulos, mas não assumiu o cargo devido a algum incidente nunca esclarecido e que sempre o magoou" (FICHER, Sylvia. Os arquitetos da Poli: ensino e profissão em São Paulo. São Paulo: Fapesp: Editora da Universidade de São Paulo, 2005, p. 339). Foi também professor livre-docente da Escola de Arquitetura de Minas Gerais (hoje pertencente à UFMG), onde fez amizade com o arquiteto e historiador Sylvio de Vasconcellos (responsável também à época pela regional mineira do SPHAN), dentre outras atividades didáticas esparsas: organizou o Curso Especial de Planejamento, na Faculdade de Arquitetura Mackenzie, e o Curso Extensivo de Planejamento, no IAB/SP, além de ter lecionado nas faculdades de Arquitetura de Salvador, Porto Alegre e Recife (Ibid, p. 339). Juliana Mota destaca ainda os cursos de planejamento que ministrou junto ao Instituto dos Arquitetos do Brasil (MOTA, op. cit.). nacional, desde que demonstrassem interesse no "engrandecimento da nação".

Desse modo, o interesse manifestado por Luís Saia pela arquitetura residencial e, em especial, popular (CARLINI, 1994), no período que vai de 1936 a 1945 (estou considerando, portanto, os anos que esteve ao lado de Mário de Andrade), relacionavase diretamente com os seus anseios acadêmicos somados ao desejo de se aprofundar no conhecimento da "alma nacional", em grande medida incentivada pela militância junto à AIB. São esses os valores contidos nos estudos que Saia realizou, nesta época, tanto a respeito da arquitetura tradicional paulista quanto no que se refere à arquitetura popular brasileira. Ambas seriam uma porta de entrada uma melhor compreensão do ethos nacional, e tanto a Sociedade de Etnografia e Folclore quanto o SPHAN proporcionariam os meios eficazes para a realização desses objetivos.

É interessante notar que, na década de 1930, a casa surgia como objeto privilegiado para a compreensão da formação cultural nacional. Embora possamos afirmar que os arquitetos chamados "neocoloniais" já viessem insistindo nesse aspecto (NATAL, 2013), foi sobretudo a partir da publicação de CasaGrande \& Senzala, em 1933, que se consolidou o entendimento de que a casa seria um espaço privilegiado para a compreensão da formação cultural brasileira. É possível afirmar que logo se estabeleceu um profícuo diálogo entre a arquitetura moderna, bem como as práticas de proteção ao patrimônio cultural, e as ideias contidas em Casa-Grande \& Senzala, sobretudo no que diz respeito às propostas encabeçadas por Lúcio Costa para a arquitetura brasileira (PUNTONI, 2001; RUBINO, 2003). A partir de então a história da arquitetura brasileira, que se institucionaliza no âmbito disciplinar da própria arquitetura (e não da história), passou a produzir o sentido demandado pela obra de construção de uma nação moderna. Seria este o caminho a ser percorrido por Saia no intuito de definir o valor da "paulistanidade" no interior da "nacionalidade".

Num segundo momento da trajetória de Luís Saia, as casas paulistas passaram a ser interpretadas por meio de uma perspectiva materialista dialética peculiar, em grande medida somada à sua formação etnográfica e em constante diálogo com a historiografia moderna brasileira produzida a partir da década de 1930. As leituras marxistas de Luís Saia se deram, provavelmente no início da década de 1940 (devemos nos lembrar que em 1942 uma grande campanha contra o eixo e, por conseguinte, contra os regimes totalitários europeus nos quais se espelhava a ideologia integralista, espalhou-se pelo país). Em 1943 o arquiteto já demonstra sua simpatia pelo marxismo num relato publicado no jornal O Estado de S. Paulo. ${ }^{18}$ Neste depoimento, relativo à sua "visão de mundo", Saia declara que para ter tal visão e agir socialmente não seria necessário "carteirinha de partido".

A adesão de Saia ao materialismo histórico é perceptível na medida em que, a partir de meados da década de 1940, possibilitou a elaboração de uma interpretação renovada da formação cultural paulista. Esta, como vimos (Tabela 1), se desenvolveria como uma sucessão de estágios determinados por uma relação dialética entre as necessidades do homem em suas relações mesológicas e de produção e as contradições que lhe eram impostas por este mesmo meio, gerando um movimento evolutivo no qual se encontraria as especificidades da cultura paulista. Trata-se, portanto, de um sentido materialista, dialético, mas muito pouco ortodoxo. Saia, que não se prendeu ao dogmatismo das interpretações históricas do marxismo-leninismo de então, percebia, no entanto, essa relação do homem com o meio como determinada por uma dependência para com as diversas formas de dominação que teriam colocado a economia e a cultura brasileira numa posição subordinada, algo a ser superado em busca de uma arquitetura e de um urbanismo verdadeiramente nacionais.

Foram essas motivações que muito provavelmente conduziram Luís Saia a uma atuação mais efetiva na área do planejamento urbano e da docência a partir da década de 1950, embora isso não se mostrasse incompatível com a manutenção das práticas de tutela do patrimônio cultural brasileiro no DPHAN (a partir de 1946 o "Serviço" tornara-se "Diretoria do Patrimônio Histórico e Artístico Nacional). ${ }^{19} \mathrm{E}$, como mostrei acima, foram esses dois aspectos, ou seja, a visão materialista dialética e as ações voltadas para o urbanismo e a docência, que conduziram à escrita dos artigos que, somados aos escritos da primeira fase, compuseram o livro Morada paulista. Saia agora somaria os saberes etnográficos e folclóricos, práticos 
20 Sobre a relação dos arquitetos modernos com os Estados latino-americanos, cf. GORELIK, Adrián. Das vanguardas a Brasília: cultura urbana e arquitetura na América Latina. Belo Horizonte: Editora UFMG, 2005

21 Sobretudo depois da apropriação que Lucio Costa fez da obra de Le Corbusier. Creio que para encontrarmos este aspecto na obra do arquiteto suíço seja suficiente a leitura da Carta de Atenas e de LE CORBUSIER. Mensagem aos estudantes de arquitetura. São Paulo: Martins, 2006. No que tange aos contatos de Lucio Costa com a obra (e pessoa) de Le Corbusier, cf. NOBRE, op. cit., 2004.

22 É possível afirmar com certeza que Saia leu o livro Dialectique de la nature, de Friedrich Engels (a Biblioteca Luís Saia conta com a edição de 1955 deste livro, profusamente fichada pelo arquiteto). Há também indícios, que ainda precisam ser melhor confirmados, de que 0 arquiteto teria adquirido $O$ Capital, de Marx (Saia trouxe da Argentina uma edição, de 1960, em 5 volumes, da editora Fondo de Cultura Económica) e de que teria lido e fichado o livro Introdução à lógica dialética, de Eli de Gortari, numa edição de 1960 (essas obras fariam parte do acervo de Saia que não teria ficado com a biblioteca da $9^{a}$ Superintendência Regional do IPHAN em SP). No entanto, Saia já poderia ter acesso, nesse período, às publicações de Georg Lukács e Antônio Gramsci, que desde a década de 1920 se preocupavam em superar o reformismo hegemônico da Segunda Internacional mediante uma retomada da dialética marxista (CARDOSO, Ciro Flamarion e BRIGNOLI, Hector Perez. Os métodos da história. $2^{\text {a }}$ ed. Rio de Janeiro: Graal, 1981; MUSSE, Ricardo. "A dialética como discurso do método". Tempo Social: Revista de Sociologia da USP, v. 17, n. 1 , junho de 2005). Além disso, segundo C. F. Cardoso, "a partir da década de 1950 e, mais ainda, do decênio seguinte, um grande debate teórico e metodológico entre marxistas de muitos países iniciou nova fase, muito mais crítica e aberta ao trabalho criador do que a anterior" (CARDOSO, op. cit.). e teóricos, adquiridos nos anos de proximidade com Mário de Andrade, a uma consciência mais ampla do processo histórico, bem como do papel de sujeito do arquiteto em sua definição. Esse profissional teria um papel transformador significativo, de modo que Saia adotou, portanto, uma postura que poderia ser considerada elitista ou mesmo vanguardista comum aos arquitetos modernos: esses profissionais teriam uma grande parcela de responsabilidade sobre os rumos da sociedade, cabendo-Ihes identificar os principais problemas urbanos (numa escala inicialmente regional) para, então, intervir de forma eficaz, visando um uso mais igualitário das cidades e à transformação do ser humano. ${ }^{20}$ Morada paulista está, assim, repleto de um sentimento que se tornou cada vez mais notável no meio arquitetônico brasileiro. ${ }^{21}$

\section{O sentido}

Saia encontrou o sentido buscado para a identidade arquitetônica e cultural paulista numa ideia de processo histórico construída a partir dos diversos componentes que constituíam o complexo cultural de sua época. Essa ideia de sentido, que ora descreverei com base em seu Morada paulista, possibilitou ao arquiteto "separar o joio do trigo", indicando quais seriam as experiências acertadas e equivocadas do passado e mostrando como o presente é fruto dessas ações pretéritas. Além disso, este sentido, expresso na forma de uma "evolução regional", possibilitaria uma interferência no processo histórico por intermédio do conhecimento de sua suposta racionalidade. O futuro poderia ser então alterado, para melhor, por intermédio de uma correta intervenção nas relações entre homem e espaço no presente, seja por meio de projetos arquitetônicos, intervenções urbanísticas ou tutela da arquitetura e do espaço urbano regional, os dois últimos dotados de valores pedagógicos.

Em primeiro lugar, convém notar que Saia não se prendeu a modelos pré-estabelecidos ao analisar a sociedade paulista em seus diferentes recortes cronológicos. Foram considerados assim os processos específicos regionais em conexão com aqueles de maior amplitude. As peculiaridades foram percebidas em seus elementos mesológicos, mediante um olhar etnográfico que relaciona cultura e sociedade às condições de economia e meio. No entanto, não se tratou de uma análise puramente estrutural: importaria conhecer os motivos pelos quais a sociedade paulista tradicional se alterou a ponto de, no presente, dever ser como que "resgatada", sob o risco de desaparecimento das "soluções regionais", consideradas as mais indicadas para um correto desenvolvimento regional e nacional a partir do presente.

Neste ponto impõe-se um questionamento fundamental para a compreensão da ideia de sentido presente na obra de Luís Saia. Essa "evolução regional paulista" seria natural ou dependente da criatividade subjetiva? Isso desloca a reflexão para os debates em torno da concepção marxista de "dialética". Tudo leva a crer que Saia tenha tido à sua disposição, inicialmente, textos produzidos por uma vertente bastante próxima do pensamento positivista e evolucionista. Foi o caso das primeiras traduções brasileiras, realizadas na década de 1930, das obras de Nicolau Bukharin, além da própria produção nacional. A partir da década de 1960, existem evidências que demonstram o interesse de Saia por um aprofundamento das questões relacionadas à dialética marxista, o que se traduziu em seus textos escritos a partir de então. ${ }^{22}$ De qualquer forma, Saia nunca buscou no marxismo modelos fechados nos quais pudesse ser enquadrada a sociedade paulista, mas uma ferramenta que pudesse explicar de forma eficaz o seu processo histórico.

É no capítulo "Quadro geral dos monumentos paulistas" que se pode encontrar a explicação mais acabada de como é compreendido o processo que denomina "evolução regional paulista". Saia divide a sociedade paulista, tomada em sua instância temporal, em "períodos" ou "ciclos" classificados de acordo com as soluções que lhes foram predominantes. O foco da análise incide em dois pontos: na descrição desses elementos predominantes de cada ciclo (economia, forma de ocupação territorial - consideradas as condições do terreno -, relações sociais, cultura e, por fim, arquitetura) e os fatores que levaram às mudanças dessas preferências

O movimento diacrônico da análise de Saia é possibilitado pelo confronto travado entre aquilo que ele chama de "teses". A partir da oposição entre os interesses econômicos e as condições do meio emergiria uma síntese expressa nos modelos predominantes de exploração econômica, ocupação 
territorial e arquitetura. Sobre essas "teses", Saia escreve o seguinte:

Cada período característico da formação regional contém pelo menos uma tese principal e uma família de teses ancilares. É possível que a hierarquização dessas teses acolha controvérsias, mas é certo, por outro lado, que é sempre possível distinguir, não só em relação à tese principal, como no que diz respeito às teses ancilares, um jogo dialético de oposições que desembocam em decididas preferências por soluções características, partidos dominantes, esquemas endossados pela maioria ou mesmo por uma quase unanimidade coletiva. Em certos casos, a proposição-tese é tão clara que o simples enunciado dela é bastante esclarecedor; em outros casos é indispensável uma análise crítica para extrair dos fatos aquele travamento ou aquelas aproximações que Ihes conferem significados expressivos, os quais de outra forma permaneceriam despercebidos (SAIA, 2005, p. 224)

É justamente a partir dessa compreensão do processo histórico que Saia pôde elaborar o "quadro teórico" que possibilitou a periodização exposta na "Tabela 1".

Pode-se afirmar, portanto, que, para Luís Saia, a evolução de um processo histórico não é nem puramente objetiva nem subjetiva, mas um confronto entre essas duas forças. Exemplo disso é o "quadro" no qual situou os monumentos paulistas. O primeiro período da evolução regional paulista, por exemplo, caracterizar-se-ia, como já foi visto, pelo confronto entre a "tese mercantilista" (ou seja, uma espécie de "teoria" que orienta a ação colonizadora, para a qual interessaria a exploração da cana-de-açúcar para a exportação) e sua "negação" (as condições topológicas e pedológicas adversas do litoral santista), do qual teria emergido uma síntese expressa numa outra tese, a da "mestiçagem intensiva", "de tudo, de gente, de técnica militar, de dieta alimentar, de linguagem, de estilo de vida" (SAIA, 2005, p. 224), o que teria possibilitado, por sua vez, uma penetração mais eficaz no interior do continente e a criação de soluções econômicas e materiais mais propícias ao meio. Desse modo, "ao sentido carismático da ação religiosa (...) se opôs, em São Paulo, uma ação colona de sentido dessacralizante, fundada na montagem de uma estrutura social de caráter feudal-militar" (SAIA, 2005, p. 28).
A ação metropolitana seria negada pelas reais condições do meio, às quais os colonizadores tiveram que se adequar por intermédio de soluções inovadoras. O meio não determinaria assim o processo social, mas influiria decisivamente nas soluções encontradas.

Da mesma forma, a "ação criativa dos sujeitos" encontraria no meio limitações às quais deveria adequar-se.

Tem-se, assim, uma sucessão de períodos ou ciclos que vão se engendrando de forma "dialética". O que ocorreria seria uma alternância entre o predomínio de soluções características, expresso em ciclos ou períodos bem demarcados cronologicamente, e a emergência de contradições sistêmicas que conduziriam à ruptura de um ciclo e ao surgimento de outro. Em cada um destes períodos seria possível identificar teses principais, ancilares e teses que foram negadas (mas que, no entanto, podem continuar existindo de forma mitigada, até que, por alguma contingência, retomem sua força acarretando a ruptura do ciclo). As sínteses identificáveis em cada período (não excluídas suas novas antíteses) levariam não só à compreensão dos partidos arquitetônicos adotados, mas de toda configuração social da região analisada em função de seus determinantes estruturais então predominantes.

Desta forma, a meu ver, seria sempre a iniciativa de um sujeito histórico (o "paulista"), buscando novas formas de produção e trabalho e engendrando, por conseguinte, novos modos de exploração social, que ocasionaria as mudanças de ciclos dentro da evolução regional, muito embora o "povo paulista" estivesse sempre condicionado pelas condições reais de vida (modos de exploração econômica, relações sociais pré-estabelecidas, disponibilidade e qualidade do solo etc.). Aqui é possível, portanto, reconhecer mais uma diferença em relação ao marxismo, visto que não se trata de uma luta de classes propriamente dita, mas da disputa entre paulistas (tanto dominadores quanto dominados) e a metrópole. A relação deste mesmo sujeito histórico com as condições objetivas de existência e a consequente criação cultural advinda dessa relação remete, por sua vez, muito mais a autores como Freyre e Buarque de Holanda, que também pensaram a história nacional de forma "evolutiva", embora o termo preferido pelos historiadores modernistas seja "formação". 
23 "A pesquisa desesperada dessa interpretação unicamente através da forma - o que leva a arquitetura modernista de São Paulo a uma exploração incansável e inútil de combinações dos elementos da linguagem plástica que incidentalmente serviram a alguns projetos nacionais mais reussidos [neologismo a partir do verbo francês réussir, que significa "ser bem sucedido"] (rampas, pilotis, brise-soleil etc.) - sobre constituir uma preocupação amazonicamente alheia à substância do verdadeiro problema, representa um desmentido à respeitável lição da arquitetura tradicional, cuja 'inteligência' e temática expressional souberam, mesmo nos momentos de atividade criadora mais discreta, manter-se num alto nível de respeito próprio, resolvendo, sem pretensões, os problemas que thes eram propostos pela comunidade (...) Se cada época e cada comunidade têm uma temática expressiva e uma intenção peculiar, é evidente teimosia pretender repetir experiências plásticas destituindo-as de senso e de funcionalidade, especialmente quando essas experiências não representam - como não representam no caso particular de São Paulo atual - a única e mais importante contribuição para a solução dos legítimos problemas regionais" (SAIA, 2005, p. 262)
A evolução regional paulista tampouco deve ser pensada de forma unilinear, mas em conexão com processos mais amplos. Os compromissos com uma "economia colonial" nunca são esquecidos, seja no período bandeirista ou no ciclo cafeeiro. Nos primeiros séculos da colonização, a sociedade paulista, embora tivesse alcançado uma relativa autonomia em relação à metrópole, teria se constituído num contexto de exploração comercial europeia e em resposta às suas tentativas mal sucedidas de colonização na zona meridional brasileira. A partir do século XIX, por sua vez, a dependência em relação à economia metropolitana seria ainda maior, determinando inclusive a adoção de costumes e gostos europeus.

Um exemplo dessa situação de dependência seria a posição subordinada ocupada pela colônia na "divisão internacional do trabalho", situação que somente no século XX passaria a ter condições de ser modificada. No período bandeirista, essa divisão teria levado a técnica, de um modo geral, a uma involução limitada ao nível do artesanato. Essa situação só não teria correspondido a uma maior pobreza técnica e artística pelo fato de que, dadas as condições de relativa autonomia em relação à metrópole, a sociedade paulista pôde selecionar de forma mais livre, através do que Saia denominou "inteligência coletiva", as soluções mais indicadas ao meio e ao modo de vida. Tal situação não se repetiria no período cafeeiro, uma vez que todas as soluções técnicas e tecnológicas foram postas a serviço dos interesses da "economia colonial", em prejuízo de soluções regionais "autênticas". A situação de dependência em relação à economia e cultura europeia seria a contradição a ser superada, segundo se depreende da leitura de Morada paulista, do momento inicial da colonização até seu presente imediato.

Desse modo, conclui-se que o sentido elaborado historicamente no intuito de conferir significado à arquitetura paulista no interior da arquitetura nacional se sustenta num materialismo dialético sui generis, mas se confunde também, em grande medida, com o sentido histórico mais amplo fornecido por uma arquitetura e historiografia modernas para a formação cultural brasileira.

Luís Saia aderiu aos preceitos da arquitetura moderna brasileira, principalmente pelo "racionalismo" que esta pregava, ou seja, a investigação das condições reais de vida que conduziriam a uma "saúde plástica perfeita", ou, em outras palavras, a um correto equilíbrio entre forma e função. Saia critica, isso sim, um outro "modernismo", praticado em São Paulo, sobretudo a partir da década de 1950. ${ }^{23}$ Desse modo, por caminhos em certa medida diversos, Luís Saia e Lucio Costa (e a arquitetura moderna por ele "liderada") acabaram por se encontrar. Todavia, ao menos um ponto de partida foi comum: a crença numa nação brasileira dotada de historicidade. E essa coincidência conduziu a percepções temporais da nação muito semelhantes, ou seja, algo que pode ser unificado numa linha evolutiva dotada de momentos de originalidade e de "submissão" cultural. Assim, o século XIX era visto como um momento em que o Brasil estava na dependência de outras potências econômicas europeias (sobretudo a Inglaterra do ponto vista econômico e a França do ponto de vista cultural), que teria interrompido um longo período de experimentação e de criação de formas originais de organização cultural e social. Seria um dever dos arquitetos colaborar com o reatar desse fio evolutivo rompido, atuando nas diversas frentes relacionadas com a modificação dos espaços de vida e convivência.

Com relação à historiografia moderna brasileira, Saia diz o seguinte:

Na década de 30, os interessados no estudo dos problemas brasileiros eram presas, quando não de um pretenso universalismo palavroso, do saudosismo aristocratizante dos Oliveira Vianna e do 'nacionalismo' de Ricardo Severo. Dois livros, Casa Grande e Senzala e Raízes do Brasil, respectivamente de Gilberto Freyre e Sérgio Buarque de Holanda, contribuíram demais como tábua de salvação (SAIA, 2005, p. 63).

Isso revela o comprometimento do arquiteto em relação a uma certa noção acerca do processo histórico nacional, que não esteve presente somente na obra desses historiadores, mas, de uma forma geral, permeou todo o pensamento modernista nesta sua fase mais nacionalista, sobretudo em função de uma busca por originalidade e destaque entre as demais nações. É possível definir esta noção como uma "essência" ou "ethos" existente por todo um período da história nacional, no qual teria predominado uma organização rural da sociedade e sobre o qual repousaria a originalidade de nossa 
civilização. Este período de formação nacional original seria interrompido bruscamente por uma série de valores "importados" em função de uma explosão urbana ocorrida a partir do século XIX. O papel de todos estes intelectuais modernistas seria, grosso modo, resgatar essa originalidade e conciliá-la com a modernização do país, única forma de retirá-lo de uma posição subordinada ante as demais nações.

Eles elementos já nos permitem compreender com mais clareza a noção de "evolução regional paulista" à luz do complexo teórico que estava disponível às ações de Luís Saia. Reconhecer nessa noção um processo dialético evita confundi-la com um evolucionismo determinista, o que reduziria em muito a compreensão da ideia que orientou as práticas preservacionistas paulistas no período analisado. Trata-se de uma ferramenta analítica que, segundo acreditou Saia, tornaria possível reconhecer os sucessivos estágios da realidade histórica paulista e, dessa forma, orientar com mais eficácia a ação da regional do IPHAN. A narrativa histórica produzida por Saia, norteada pela noção de "evolução regional paulista", pôde ser traduzida num sério esforço de assegurar a validade do trabalho ao qual se lançou com tanto afinco ao longo de seus últimos 38 anos de vida.

\section{As ações preservacionistas}

Embora essa longa análise do livro Morada paulista seja necessária para a compreensão do objeto aqui abordado, ela não é suficiente para que seja abarcada a realidade mais ampla de uma ação racional efetuada por meio de texto de história. Isso também demanda a análise dos efeitos dessa ação, para a qual devem ser levados em conta não só as motivações do ator, mas também as condições objetivas de sua efetivação. É imperativo, portanto, investigar o nível normativo da produção historiográfica (ou seja, a forma pela qual ela delimita identidades e orienta condutas a partir da organização da consciência histórica) no âmbito prático ao qual se destina. No caso em tela, a produção historiográfica deve ser relacionada às práticas preservacionistas paulistas, de modo que seu papel normativo seja melhor entendido.

Em primeiro lugar, seria interessante correlacionar os tombamentos efetivados pela regional paulista do IPHAN no período em que Saia esteve à frente deste órgão (50 num universo de 58, considerando dados recolhidos até 2008) com a produção historiográfica acima analisada.

A produção historiográfica levada a efeito por Luís Saia se intensificou na década de 1950, quando a questão urbana se torna fundamenta em sua obra. No entanto, o arquiteto já havia publicado dois importantes artigos: "Os alpendres nas capelas brasileiras", de 1939, e "Notas sobre a arquitetura rural paulista no segundo século", de 1944, além de ter contribuído com o artigo de Mário de Andrade sobre a capela de Santo Antônio publicado em 1937. Do total dos bens tombados durante a atuação de Luís Saia, 17 tombamentos foram realizados até o final da década de 1940 Isso indicaria que todos esses bens foram tombados sem o apoio dos critérios históricos elaborados mais consistentemente após a década de 1950, ou seja, sem que estivessem amparados na construção teórica fundamentada na noção de "evolução regional paulista", mas apenas numa definição já precisa dos "tipos" que conformariam a arquitetura tradicional paulista.

É a partir da década de 1950 que se amplia o lapso temporal no qual estão inseridos os bens tombados pelo IPHAN. Com exceção dos ciclos mais recentes (ou seja, aqueles posteriores à expansão ferroviária ocorrida no território paulista), todos os demais (vide "Tabela 1") possuem ao menos um representante típico tombado. Da "arquitetura de circunstância", é possível citar a "Casa Sede da Fazenda Engenho d'Água", em Ilhabela; do ciclo cafezista ("economia de sobremesa"), foi tombada, entre outros edifícios, a "Fazenda Pau d'Alho", considerada um tipo "clássico" do período pelo arquiteto; do ciclo ferroviário, a "Casa de Prudente de Morais", em Piracicaba, ou o "Edifício do Museu Republicano da Convenção de Itu". Do período chamado "intermezzo roceiro", talvez se pudesse incluir a "Casa Natal de Oswaldo Cruz", em São Luís do Paraitinga, que se ligaria mais àquele " $5^{\circ}$ ciclo" apresentado em "Quadro geral dos monumentos paulistas", ao qual pertenceu esta cidade.

Não seria de todo justo afirmar que, de qualquer forma, a regional paulista do IPHAN acabou por por simplesmente reproduzir um patrimônio "pedra e cal". É necessário considerar as limitações materiais da instituição, ao lado da posição subordinada de Saia em relação às diretrizes cariocas. 
24 As cartas de Mário de Andrade ao seu superior e amigo Rodrigo indicam claramente essa escassez, pois o polígrafo teve que pagar os seus assistentes - dentre eles Luís Saia - com seus próprios "cobres" (ANDRADE, op. cit., 1981, p. 67), além de abrigar inicialmente a regional paulista do SPHAN em sua própria casa.
25 A experiência a respeito dessas ações encontra-se reunida num conjunto de entrevistas realizadas por Eduardo Costa com antigos funcionários da instituição (COSTA, 2010).
Além disso, o pequeno número de bens tombados em São Paulo (em comparação ao total de tombamentos efetuados pelo IPHAN) poderia indicar a pouca relevância do trabalho da regional paulista para a definição de uma memória e identidade nacionais. No entanto, este argumento não é condizente com a autoridade que Saia conquistou no meio preservacionista, nem com o lugar que a arquitetura bandeirista adquiriu na história da arquitetura brasileira. Além da já mencionada escassez de recursos ${ }^{24}$ os tombamentos implicavam na proteção, conservação e restauro de monumentos tombados numa ampla região geográfica do país, não restrita apenas ao estado de São Paulo, por um contingente bastante reduzido de funcionários. Mas o aspecto mais importante a se ressaltar em relação ao papel da regional paulista no interior do órgão federal diz respeito ao bom grau de autonomia que conseguiu conquistar

A decisão final de fato cabia ao Diretor de Estudos e Tombamentos, ou seja, Lucio Costa. Isso demonstra o caráter centralizador da burocracia vigente durante o Estado Novo: Vargas confiou uma série de poderes a Gustavo Capanema, que, por sua vez, delegou alguns deles a Rodrigo Melo Franco de Andrade que, por fim, confiou a Lucio Costa as decisões sobre todos os aspectos ligados ao tombamento e à manutenção dos bens tombados. Assim, pode-se depreender que o aparato burocrático do governo Vargas estruturou-se por intermédio de uma série de redes interpessoais que garantiam um relativo controle das decisões políticas e administrativas nas mãos do Presidente da República. Entre a atuação de Saia e o gabinete ditatorial havia apenas três homens, todos da mais estrita confiança do presidente.

No entanto, essa consistente rede não é suficiente para assegurar um total controle das ações de todos os indivíduos subordinados ao poder central. A análise das ações individuais se mostra assim fundamental para uma averiguação mais correta do funcionamento de aparatos institucionalizados como este no qual Luís Saia se inseriu. Existem trabalhos que mostram o grau de arbitrariedade conquistado nas restaurações levadas a cabo pela regional paulista sob a chefia do arquiteto paulista (ANDRADE, 1992; GONÇALVES, 2007). Mesmo que com o "nariz torcido", ou seja, ainda que a contragosto, Lucio Costa acabou acatando, por exemplo, as sugestões de Saia para os beirais e torre sineira da Igreja de Embu. Da mesma forma, foi aceita a ideia para o gradil lateral da Igreja de São Miguel Paulista, a demolição da "casa do Barão", no Sítio de Santo Antônio em São Roque, a extensão total da casa grande restaurada na mesma localidade e a feição do alpendre de sua capela (sempre com a desconfiança de Lucio Costa). Nem mesmo a autoridade de Paulo Tedim Barreto, que publicou um artigo versando sobre a tipologia das casas de câmara e cadeia brasileiras (1997), foi suficiente para impedir que Saia se baseasse na sua teoria sobre a evolução regional paulista e restaurasse a Casa de Câmara e Cadeia de Atibaia da forma como ela se encontra atualmente nessa cidade, em oposição a técnicos influentes da Direção Central do SPHAN, a exemplo do próprio Barreto e de Edgard Jacintho da Silva.

Esses episódios são capazes de demonstrar que, mais que a imposição de um consenso por parte da direção central do órgão estatal, O SPHAN estruturou sua atuação (e a base de conhecimento para as atuações posteriores) na acomodação de dissensos. Para tanto, realizou-se um acordo em torno de um consenso mínimo (ou seja, a incessante pesquisa das raízes da nacionalidade e a utilização prática disso para a modernização do país) e do estabelecimento de consensos secundários com base na autoridade demonstrada pelos atores em questão. Luís Saia conquistou sua autoridade neste campo através das pesquisas que levou a cabo e, sobretudo, pela apresentação historiográfica de suas ideias, produzindo uma argumentação lógica de difícil refutação pelos pares.

Mas a ação da regional paulista não ficou restrita à proteção do patrimônio arquitetônico. A este respeito, é necessário levar em conta o imenso trabalho de remanejamento fotográfico realizado nesse órgão, o "Inventário de Artes Menores", o papel central desempenhado no "Encontro de Governadores de Salvador", em 1970, com a posterior assinatura do compromisso de Brasília, a exposição intitulada "Madeira e Civilização" e uma série de outros trabalhos que ainda merecem melhor investigação. ${ }^{25}$

Entre esse conjunto de ações realizadas a partir da década de 1970 (certamente em função da maior abertura conceitual possibilitada pela gestão de 
Renato Soeiro), é necessário destacar ainda a criação do Conselho de Defesa do Patrimônio Histórico, Artístico, Arqueológico e Turístico do Estado de São Paulo (CONDEPHAAT), em 1969. Antes mesmo das discussões realizadas em Salvador e em Brasília a respeito da necessidade de descentralização da gestão do patrimônio cultural brasileira e da necessidade de colaboração entre as repartições públicas e as universidades, este órgão estadual, em grande medida influenciado por Saia (RODRIGUES, 2000), já colocava em prática aspectos que passariam a contribuir para a renovação das práticas preservacionistas no país. Além da proteção mais descentralizada do patrimônio regional, é necessário destacar o Curso de Conservação e Restauro realizado na FAU-USP em 1974, ao qual voltarei a seguir.

\section{Ressignificações}

Para concluir esse artigo, gostaria ainda discorrer sobre as apropriações posteriores da obra de Luís Saia após a sua morte em 1975. Elas podem ser resumidas, em grande medida, a uma disputa pela definição de um lugar de fala legítimo para a produção de uma história da arquitetura paulista e, por conseguinte, de seus significados para uma história da arquitetura brasileira.

Retornemos ao curso de Conservação e Restauro de 1974. Esse curso foi coordenado por Nestor Goulart Reis Filho, representante da FAU, Ulpiano Bezerra de Menezes, diretor do CONDEPHAAT, e Luís Saia, diretor regional do IPHAN. Os trabalhos que se referem a esse curso o apresentam como uma espécie de "divisor de águas" dentro das práticas preservacionistas paulistas (RODRIGUES, 2000; ANDRADE, 1992; LEMOS, 1987; LEMOS et al., 2008). Isso teria sido possibilitado pela noção mais abrangente de patrimônio proposta por Hugues de Varine-Boham, consultor da Unesco, na qual são contemplados o meio ambiente, o conhecimento e todos os "bens culturais", compreendidos como sendo "tudo que o homem fabricou". Assim, Varine-Boham teria apresentado, segundo Rodrigues, uma "definição antropológica" de patrimônio (RODRIGUES, 2000). Além disso, os cursos ministrados por Benedito Lima de Toledo e Augusto da Silva Teles teriam apontado as falhas das práticas de restauro e conservação aplicadas até então, trazendo à tona os preceitos ainda não aplicados da Carta de Veneza.
Por um lado, a realização desse curso atendia às recomendações dos compromissos de Brasília e Salvador, que mencionavam a realização de cursos de especialização na área de preservação e conservação e a realização de parcerias entre o IPHAN e as universidades (em grande medida por iniciativa do próprio Saia). Por outro, preparava a FAU para a implantação de cursos de pós-graduação em arquitetura e urbanismo, inexistentes à época no país. Contudo, a principal consequência trazida por esse curso talvez não tenha sido prevista por seus organizadores (principalmente por Luís Saia), e para que seja possível compreender essa afirmação é necessário levantar alguns questionamentos à literatura que trata do assunto.

Não restam dúvidas de que esse curso foi de fato marcante no campo das práticas preservacionistas paulistas, e talvez até mesmo nacionais (vez que antecede em um ano a grande reviravolta ocorrida no IPHAN com a criação do Centro Nacional de Referência Cultural - o CNRC -, liderado por Aloísio Magalhães). Personagens importantes desse território, a exemplo do próprio Nestor Goulart Reis Filho e Carlos Lemos já lembraram como esse curso foi importante em suas respectivas trajetórias individuais e para o "Patrimônio" em São Paulo, em geral (REIS FILHO, 1997; LEMOS, 2005).

No entanto, mais do que uma renovação conceitual, percebe-se que se trata da emergência de novos atores em disputa pelo campo da arquitetura e do patrimônio arquitetônico paulista. A partir de então, a Faculdade de Arquitetura e Urbanismo da USP passa a se colocar como alternativa à história da arquitetura produzida no âmbito do IPHAN. Os "novos trabalhos" defendem um maior rigor metodológico em oposição aos trabalhos supostamente mais amadorísticos e inexperientes do IPHAN, sobretudo os de Luís Saia. Carlos Lemos seria o fundador dessa postura, adotando uma definição mais "antropológica" de cultura e baseando-se na leitura de documentação "primária" (LEMOS, 1999, p. ex.). Seus epígonos tratariam de reafirmar a invenção dessa nova tradição, conformando assim uma estratégia de legitimação e institucionalização de um locus de autoridade discursiva.

No entanto, a afirmação de um suposto desconhecimento de Luís Saia acerca da documentação primária relativa ao patrimônio cultural paulista tem 
26 Uma série de trabalhos acadêmicos recentes vem tratando de maneira pormenorizada das ações realizadas no Departamento de Cultura, em especial no que se refere à SEF. Dentre os mais recentes, destacaria VIAL, 2009, VALENTINI, 2010, SODRÉ, 2010, SENA, 2011.

27 Além do já mencionado TRINDADE, 2012, merece destaque a recente exposição, intitulada Luís Saia: memória e política, realizada entre 2011 e 2012 por ocasião do centenário do nascimento do arquiteto, cujo catálogo foi recentemente publicado em ANDRADE, Carlos Roberto Monteiro de [Coord., et al.]. Luís 2014. Luís Saia: memória e política. Brasília, DF: IPHAN, 2014.

28 A esse respeito merecem destaque os trabalhos produzidos por Carlos Gutierrez Cerqueira e publicados em CERQUEIRA, Carlos G. F.; SAIA NETO, José. Pesquisas em torno de um monumento. [Brasilia:] IPHAN/MinC, s.d., e em seu blog pessoal.

29 Em minha dissertação de mestrado, defendida em 2010, apresento uma visão um pouco mais completa, embora também nem de longe exaustiva, da atuação de Luís Saia, ao lado das ações empreendidas por Nestor Goulart Reis Filho, visando a entender melhor como os trabalhos em torno da história da arquitetura e do urbanismo paulista contribuíram para a definição do patrimônio cultural nacional (LOWANDE, 2010). sido alvo de sérias contestações (TRINDADE, 2012). Da mesma forma, continuar afirmando que uma "abordagem antropológica" apenas aportou no IPHAN a partir da década de 1970 é, no mínimo, desconsiderar a ampla formação antropológica proporcionada pelo Departamento de Cultura, em especial a partir do Curso de Etnografia e Folclore de $1936,{ }^{26}$ que veio a embasar as ações da regional paulista do IPHAN, ou o papel destacado desempenhado pelo Museu Nacional da Quinta da Boa Vista na definição dos rumos da instituição em nível federal. Desse modo, a principal mudança representada pelo Curso de Conservação e Restauro de 1974 talvez tenha sido a menos considerada: a progressiva ocupação de um espaço disponível nesse campo pela FAU, espaço estratégico quando o que importa é a autoridade na produção e no ensino da história da arquitetura.

De outro lado, de maneira bem mais frágil no que se refere ao respaldo institucional, antigos funcionários do IPHAN, não ligados à FAU e já aposentados ou ainda em atividade, têm se esforçado no sentido de defender as realizações de Luís Saia no órgão federal. Isso tem sido feito seja por meio do resgate da produção do arquiteto paulista em textos acadêmicos ou exposições, ${ }^{27} \mathrm{ou}$ mesmo em pesquisas que retomam as hipóteses iniciadas por ele e que ainda não receberam a devida atenção. ${ }^{28}$ Estes trabalhos têm fornecido importantes elementos para uma releitura recente da história das práticas preservacionistas em São Paulo e no Brasil.

Este artigo possui uma pretensão bem mais modesta do que propor uma revisão historiográfica abrangente acerca dessas práticas. Seu intuito foi apenas apontar o significado de uma trajetória individual a partir de uma metodologia mais afeita à área da história da historiografia. Esse recorte não permite também dar conta de toda a extensão da obra de Luís Saia, ${ }^{29}$ e certamente outros trabalhos serão necessários para fazer jus ao conjunto da obra desse arquiteto. No entanto, acredito ser um passo importante mostrar que a trajetória IPHAN, mais do que a sucessão de grandes consensos em torno de seus principais dirigentes, comportou e acomodou inúmeros dissensos em seu interior. Entender as práticas intelectuais de construção da nacionalidade por meio de práticas de preservação de seu patrimônio cultural como um "campo" pressupõe percebê-lo como espaço de constantes conflitos e acomodações, de disputa por posições e por autoridade, e menos como um instrumento unívoco de dominação estatal. Também neste caso, trata-se de uma instituição cujo sentido é o conflito pelo exercício local do poder, e no IPHAN, assim como na política e administração geral brasileira, o equilíbrio sempre esteve pautado numa constante negociação com os interesses regionais e locais.

\section{Referências bibliográficas}

AMOROSO, Marta. Sociedade de Etnografia e Folclore (1936-1939). "Modernismo e Antropologia". In: CENTRO DE CULTURA DE SÃO PAULO. Catálogo da Sociedade de Etnografia e Folclore. São Paulo, 1993. Disponível em <centrocultural.sp.gov.br/livros/ pdfs/sef.pdf>.

ANDRADE, Carlos Roberto Monteiro de [Coord., et al.] Luís 2014. Luís Saia: memória e política. Brasília, DF: IPHAN, 2014

ANDRADE, Antônio Luís Dias de. "O nariz torcido de Lucio Costa". Sinopses, São Paulo, n. 18, p. 5-17, dez. 1992.

ANDRADE, Mário de. Cartas de trabalho: Correspondências com Rodrigo Mello Franco de Andrade, 19361945. Brasília: Secretaria do Patrimônio Histórico e Artístico Nacional: Fundação Pró-Memória, 1981.

ANDRADE, Rodrigo Melo Franco de. Rodrigo e o SPHAN Rio de Janeiro: Ministério da Cultura, Secretaria do Patrimônio Histórico e Artístico Nacional, Fundação Nacional Pró-Memória, 1987.

BARRETO, Paulo Thedim. "Casas de Câmara e Cadeia". Revista do Patrimônio, [Brasília] n. 26, p. 362-443, 1997.

BRAGA, Vanuza Moreira. Relíquia e esperança: Ouro Preto e as políticas de preservação do patrimônio no Brasil. In FERREIRA, Marieta de Morais [org.]. Memória e identidade nacional. Rio de Janeiro: Editora FGV, 2010

BOURDIEU, Pierre. "O campo científico". In ORTIZ, Renato [org.]. Pierre Bourdieu: sociologia. São Paulo: Ática, 1983.

CALIL, Carlos Augusto Machado. "Sob o signo do Aleijadinho: Blaise Cendrars precursor do Patrimônio Histórico". In: ANDRADE, Antônio Luís Dias [et al.]. Patrimônio: atualizando o debate. São Paulo: 9a SR/ IPHAN, 2006.

CARDOSO, Ciro Flamarion e BRIGNOLI, Hector Perez. Os métodos da história. $2^{a}$ ed. - Rio de Janeiro: Graal, 1981.

CARLINI, Álvaro. Cantem lá que gravam cá: Mário de Andrade e a Missão de Pesquisas Folclóricas de 1938. Dissertação (Mestrado em História). - Departamento de História da Faculdade de Filosofia, Letras e Ciências Humanas da Universidade de São Paulo, 1994.

CERQUEIRA, Carlos G. F.; SAIA NETO, José. Pesquisas em torno de um monumento. [Brasília:] IPHAN/ MinC, s.d. 
DIAS, Carla da Costa; LIMA, Antônio Carlos de Souza. "O Museu Nacional e a construção do patrimônio histórico nacional. Revista do Patrimônio Histórico e Artístico Nacional, Brasília, n. 34, p. 199-222, 2012.

DUARTE, Paulo. Mário de Andrade por ele mesmo. São Paulo: EDART - São Paulo Livraria Editora LTDA., 1971

FICHER, Sylvia. Os arquitetos da Poli: ensino e profissão em São Paulo. São Paulo: Fapesp: Editora da Universidade de São Paulo, 2005.

GORELIK, Adrián. Das vanguardas a Brasília: cultura urbana e arquitetura na América Latina. Belo Horizonte: Editora UFMG, 2005

HABERMAS, Jürgen. Técnica e ciência como "ideologia". In Técnica e ciência como "ideologia". Lisboa: Edições 70, [1968].

HOCHMAN, Gilberto. "A ciência entre a comunidade e o mercado: leituras de Kuhn, Bourdieu, Latour e Knorr-Cetina". In PORTOCARRERO, Vera [org.]. Filosofia, história e sociologia das ciências I: abordagens contemporâneas. Rio de Janeiro: Editora FIOCRUZ, 1994.

KOSELLECK, Reinhart. Futuro passado: contribuição à semântica dos tempos históricos. Rio de Janeiro: Contraponto: Ed. PUC-Rio, 2006.

LATOUR, Bruno; WOOLGAR, Steve. A vida de laboratório: a produção dos fatos científicos. Rio de Janeiro: Relume Dumará, 1997.

LE CORBUSIER. Mensagem aos estudantes de arquitetura. São Paulo: Martins, 2006.

LEMOS, Carlos Alberto Cerqueira. O que é Patrimônio Histórico? $5^{a}$ ed. - São Paulo: Brasiliense, 1987.

Casa paulista: história das moradias anteriores ao ecletismo trazido pelo café. São Paulo: Editora da Universidade de São Paulo, 1999

Viagem pela carne. São Paulo: Editora da Universidade de São Paulo, 2005.

LEMOS, Carlos Alberto Cerqueira; MORI, Victor Hugo; ALAMBERT, Clara Correia d'. Patrimônio: 70 anos em São Paulo. São Paulo: 9a SR/IPHAN, 2008.

LOWANDE, Walter Francisco Figueiredo. Os sentidos da preservação: história da arquitetura e práticas preservacionistas em São Paulo. Dissertação (Mestrado em História). - Instituto de Ciências Humanas e Sociais, Universidade Federal de Ouro Preto, Mariana, 2010

Orientando-se em meio a lapsos: considerações sobre a produção historiográfica relativa às políticas públicas de preservação patrimonial no Brasil. Revista CPC. São Paulo, n. 15, p. 50-66, nov. 2012-abr. 2013.

"Para além da pedra e cal: o Museu Nacional e as ações de preservação do patrimônio arqueológico e etnográfico (1937-1955). História Social, Campinas, 2014, no prelo.

MAYUMI, Lia. Taipa, canela preta e concreto: um estudo sobre a restauração de casas bandeiristas em São Paulo. Tese (Doutorado em Arquitetura e Urbanismo). - Pós-Graduação em Arquitetura e Urbanismo, Facul- dade de Arquitetura e Urbanismo da Universidade de São Paulo, 2005

MOTA, Juliana Costa. Planos diretores de Goiânia, década de 60: a inserção dos arquitetos Luís Saia e Jorge WiIheim no campo do planejamento urbano. Dissertação (Mestrado em Egenharia). - Escola de Engenharia de São Carlos, Universidade de São Paulo, 2004.

MUSSE, Ricardo. "A dialética como discurso do método". Tempo Social: Revista de SocIologIA DA USP, v. 17, n. 1, junho de 2005.

NEME, Mário [org.]. Plataforma da Nova Geração. Porto Alegre: Globo, 1945

NATAL, Caion Meneguello. Da casa de barro ao palácio de concreto: a invenção do patrimônio arquitetônico no Brasil (1914-1951). Tese (Doutorado em História). Instituto de Filosofia e Ciências Humanas, Universidade Estadual de Campinas, Campinas, 2013.

NOBRE, Ana Luiza et. al. [Orgs.]. Um Modo de ser moderno: Lucio Costa e a crítica contemporânea. São Paulo: Cosac \& Naify, 2004

PUNTONI, Pedro. A casa e a memória: Gilberto Freyre e a noção de patrimônio histórico nacional. In FALCÃO, J. e ARAÚJO, R. M. B. de. [orgs.]. O Imperador das idéias: Gilberto Freyre em questão. Rio de Janeiro: Colégio do Brasil; UniverCidade; Fundação Roberto Marinho; Topbooks, 2001.

REIS FILHO, Nestor Goulart. "Algumas raízes". In Notas sobre a História da Arquitetura e aparência das vilas e cidades. São Paulo: FAU-USP, 1997. (Cadernos de Pesquisa do LAP $n^{\circ} 20$.

RODRIGUES, Marly. Imagens do passado: a instituição do patrimônio em São Paulo: 1969-1987. São Paulo: Editora UNESP: Imprensa Oficial do Estado: CONDEPHAAT: FAPESP, 2000

RUBINO, Silvana. "A memória de Mário". Revista do Patrimônio Histórico e Artístico Nacional. [Brasília], n. 30, p. $138-155,2002$

"Entre o CIAM e o SPHAN: diálogos entre Lucio Costa e Gilberto Freyre". In VOLFZON, Ethel et. al. [orgs.]. Gilberto Freyre em quatro tempos. Bauru, SP: EDUSC, 2003

RÜSEN, Jörn. Razão histórica: teoria da história: os fundamentos da ciência histórica. Brasília: Editora da Universidade de Brasília, 2001

História viva: teoria da história: formas e funções do conhecimento histórico. Brasília: Editora da Universidade de Brasília, 2010.

SAIA, Luís. "Até os 35 anos, a fase heroica" CI Arquitetura: 40 anos do Patrimônio Histórico. São Paulo, FC Editora, n. 17, 1977.

Morada Paulista. $3^{a}$ ed. - São Paulo: Perspectiva, 2005.

SARLO, Beatriz. Tempo passado: cultura da memória e guinada subjetiva. São Paulo: Companhia das Letras, 2007.

SCHWARCZ, Lilia Moritz. Espetáculos das Raças: cientistas, instituições e questão racial no Brasil 1870-1930. São Paulo: Companhia das Letras, 1993. 
SENA, Tatiana da Costa. Relíquias da nação: a proteção de coleções e acervos no patrimônio (1937-1979). Dissertação (Mestrado em História). - Programa de Pós-Graduação em História, Política e Bens Culturais, CPDOC/FGV, Rio de Janeiro, 2011.

SODRÉ, João Clark de Abreu. Arquitetura e viagens de formação pelo Brasil: 1938-1962. Dissertação (Mestrado em Arquitetura e Urbanismo). - FAUUSP, São Paulo, 2010.

TRINDADE, Jaelson Bitran. "Patrimônio e história: a abordagem regional". Revista do Patrimônio Histórico e Artístico Nacional, Brasília, n. 34, p. 303-336, 2012.

VALENTINI, Luísa. Um laboratório de antropologia: o encontro entre Mário de Andrade, Dina Dreyfus e Claude Lévi-Strauss (1935-1938). Dissertação (Mestrado em Antropologia Social). São Paulo: Programa de Pós-Graduação em Antropologia Social, FFLCH/ USP, 2010.

VIAL, Andréa Dias. O colecionismo no período entre- guerras: a contribuição da Sociedade de Etnografia e Folclore para a formação de coleções etnográficas. Dissertação (Mestrado em História). - Faculdade de Filosofia, Letras e Ciências Humanas, Universidade de São Paulo, São Paulo, 2009. 